"Dr Lazar Vrkatić" Faculty of Law and Business Studies

Union University

Serbia

\title{
TRANSLATING CULTURE-SPECIFIC ITEMS IN LITERARY TEXTS: PROBLEMS AND STRATEGIES IN STUDENTS' TRANSLATIONS
}

\begin{abstract}
The aim of this paper is to present the results of a study based on the translation of 4 excerpts from literary texts that contain culture-specific items (CSIs). The study involved 45 fourth-year students of English at the Faculty of Law and Business Studies Dr Lazar Vrkatic, who were required to translate 20 CSIs from the 4 passages as part of the final test. The translations were analysed, focusing on different translation strategies, as well as on the causes of any mistranslations. The results reveal to which degree students have developed an awareness of cultural differences and the importance of understanding and successfully transferring CSIs into the target culture.
\end{abstract}

Key words: culture-specific items, literary texts, translation strategies, students' translations

\section{Introduction}

For a cross- and intercultural communication to be effective, the participants need to know the lexis and grammar of a foreign language, but even more importantly, they need to have a strong awareness of cultural diversity phenomena (Novakov 2016: 109). In the context of university education in English, one of the goals is to create competent communicators in all these aspects. Contemporary curricula in English studies typically consist of courses which aim to develop both linguistic and cultural competencies: language skills, linguistics, literature, translation, and cultural courses. In accordance with Standards three and four of the 'Rules and standards' issued by the Commission for Accreditation and Quality Assurance of the Republic of Serbia, higher education institutions in Serbia are required to name goals and competencies for each study programme. At $\mathrm{FLV}^{1}$ the aimed competencies of English language studies (Bachelor) include communicative competence ${ }^{2}$ as a goal in itself and also an inseparable aspect of all other competencies.

\footnotetext{
* "Dr Lazar Vrkatić" Faculty of Law and Business Studies, Union University, Bulevar Oslobođenja 76, 21000 Novi Sad, Serbia; e-mail: ana.sentov@gmail.com

${ }^{1}$ FLV stands for Faculty of Law and Business Studies dr Lazar Vrkatić, Union University

${ }^{2}$ Full list of competencies can be found at http://www.flv.edu.rs/.
} 
The concept of communicative competence was first introduced by Hymes $(1966,1972)$, as a response to the perceived inadequacy of Chomsky's definition of "linguistic competence" (1965) from a sociolinguistic perspective (Celce-Murcia et al. 1995: 10). The notion that language proficiency involves both the grammatical knowledge of phonology, morphology, syntax, etc. and the social knowledge about how and when to use utterances appropriately underlies the communicative approach to second language teaching and learning. The seminal model of communicative competence was developed by Canale and Swain (1980), and further elaborated by Canale (1983). This model specified four components of communicative competence: grammatical, sociolinguistic, discourse and strategic competence. Celce-Murcia et al. (1995: 10-11) narrowed down the broad concept of sociolinguistic competence and named it "sociocultural competence", stating that it is necessary to possess sociocultural knowledge to successfully employ the resources in other components (linguistic, strategic, actional and discourse competence).

The changing status of English from one of the dominant world languages to the global language - lingua franca (cf. Graddol 1997; James 2008; Novakov 2016), invites the consideration of the meaning of sociocultural competence for English language learners and teachers. The number of speakers of English as a second language has already surpassed that of its native speakers, and this will have an impact on the approaches to learning and teaching English. One of the possible outcomes may be that English as a lingua franca will be learned and taught as a neutral communication tool between different cultural groups. Graddol (1997) remarks that the increasing adoption of English as a second language has led to the growing assertiveness of non-native speakers, who see English as a tool with which they can express their own values and identities, create their own intellectual property, and export their goods and services to other countries. Thus, it may be justified to include intercultural competence as one of the goals of language studies.

\subsection{Intercultural communication and translation}

The Intercultural Communication and Translation course aims to teach students to accept cultural diversity in different environments and work with and for people of various backgrounds. Recognizing how cultural differences are reflected in the source language (SL) and finding ways to correctly convey those differences into the target language (TL) is one of the course's objectives. With this in mind, one of the assignments that students are given is to translate passages containing culture-specific items (CSIs) from English into Serbian as part of their final exam. The students are given approximately 350-word-long passages, but are instructed to translate only the sentences in bold (those containing CSIs) and to pay particular attention to the 
underlined words and phrases (the CSIs), what they refer to and what meaning they intend to convey. The students are allowed to use paperback and/or online dictionaries, and also to Google the CSIs. They are also instructed to maintain the colloquial/formal tone of the passage, its linguistic and stylistic features, and to attempt to transfer the implications/meanings as faithfully as possible.

Before taking the Intercultural Communication and Translation course in their fourth year, the FLV students have already had three courses in translation: two in their third year, and one in their fourth year. The first one is Translation Techniques, which introduces the basic principles and techniques of translation, while the other two, Translating General and Legal Texts and Translating Scientific and Professional Texts, deal with the more specific aspects of translation. Consequently, the students should already be familiar with translation procedures and strategies in general.

One of the topics of Intercultural Communication and Translation is recognizing CSIs and the translation procedures that can be employed to transfer them to the target language/culture. The course also aims to focus on the link between language, culture and translation. During classes, students were given examples of CSIs in literary and non-literary texts and encouraged to offer suitable translations for them, or to improve the already existing ones. The goal was to prepare them for the translation assignment, drawing on their knowledge from the previous translation courses, and introducing new translation procedure taxonomies, such as Davies's (2003: 72-89).

\subsection{Translating CSIs}

In an increasingly multicultural world, there is a growing awareness of the role of culture in translation, as well as of the role of translators as active mediators between the source culture (SC) and the target culture (TC). It has long been acknowledged that the meaning a text carries depends on how knowledgeable a translator is about both the SC and TC (Ceramella 2008: 16). Many translation scholars have stressed that the concept of culture is essential for understanding the importance of culture-specific items in translation (Larson 1984; Newmark 1988; Gambier 2004). Culture has been defined as a way of life and a complex system of beliefs, values, attitudes and rules which a group of people share (Larson 1984). Culture encompasses language, history, social structure, religion, tradition and daily life of a group, and is reflected in culturespecific features and items in the language (Newmark 1998: 95). In order to be able to translate such items adequately into the TL/TC, the translator not only has to be proficient in the SL, but also profoundly knowledgeable about the SC.

Whether they are called "cultural words" (Newmark 1988), "culture-specific items" (Baker 1992), "culturemes" (Nord 1997), "culture-specific references" (Davies 2003; Gambier 2004), "culture-bound concepts" (Ceramella 2008), "cultural terms" 
(Fernandez Guerra 2012) or "culture-related elements" (Novakov 2016), scholars agree that these items reflect the SC, and that a successful translation often depends on the translator's ability to use the cultural approach and think of translation as a process of communication between cultures, as well as between languages.

The cultural approach involves identifying and understanding culture-bound elements in the SL, and then integrating them in the TL translation using the translator's extra-linguistic knowledge. This approach also involves the translators doing research of their own, using printed and online sources, in a quest for the most adequate translation for the TC audience (Novakov 2016). The importance of the cultural approach cannot be overestimated: through adequate translation and the translators' remarks and explanations readers are able to understand the communicative purpose of the text, and become familiar with some aspects of the SC and, more often than not, of their own culture (Sentov 2017).

The problems that arise from the presence of CSIs in the source text have often been discussed within a framework of different taxonomies and procedures for dealing with them (cf. Newmark 1988; Baker 1992; Hervey and Higgins 1992; Aixela 1996; Davies 2003). As Davies (2003: 69) notes, these discussions have often revolved around the distinction between two basic goals of translation: preserving the features of the source text as faithfully as possible, even if this yields an exotic or strange effect, or adapting it into a target text which will be familiar and accessible to the target audience. These two strategies are usually seen as the opposite ends of a continuum: in Venuti's (1995) terms, foreignization as opposed to domestication of the target text.

In recent years, the rapid and very often indiscriminate influx of loanwords, Anglicisms in particular, into the Serbian language, has led to what the leading Serbian linguists today (e.g. Bugarski, Klajn ${ }^{3}$, Prćić) termed Anglo-Serbian (anglosrpski) - a hybrid language characterized by an excessive use of English lexical and grammatical structures, transposed into Serbian without adaptation, resulting in incorrect language use or incorrect translation (cf. Prćić et al. 2001). This, in turn, has raised concerns about the future prospects of the Serbian language among the Serbian scholars and the wider public. The Serbian language and, by extension, the Cyrillic script, are often perceived as being threatened or jeopardized by an overwhelming influence of English as a de facto global lingua franca. ${ }^{4}$ The most recent attempt at protecting the status of the Serbian language and the Cyrillic script is Cultural Development Strategy of Serbia 2017-2027 (Strategija razvoja kulture Republike Srbije 2017-2027). ${ }^{5}$

\footnotetext{
${ }^{3}$ https://web.archive.org/web/20080516115022/http://www.nin.co.yu/2002-01/17/21509.html

${ }^{4}$ https://www.autonomija.info/ranko-bugarski-price-o-ugrozenosti-cirilice-sluze-da-prikriju-veliki-brojnepismenih.html

${ }^{5}$ http://www.kultura.gov.rs/docs/dokumenti/nacrt-strategije-razvoja-kulture-republike-srbije-od-2017--do2027-/-nacrt-strategije-razvoja-kulture-republike-srbije-od-2017--do-2027-.pdf
} 
On the other hand, the appeals of linguists and language professionals to try and regulate the number of loanwords and Anglicisms that are being adopted appear to have little effect against the power of media, social networks and technology, where Anglicisms are most readily accepted. It would follow, therefore, that the foreignization strategy is prevalent in translation and that young people in Serbia have become used to it to such an extent that they might not find the preservation of source text features in the target text either "strange" or "exotic". This, in turn, might present a dilemma with regard to translation courses at the tertiary level: should teachers warn students against foreignization and insist on domestication? Or should they try to find a balance between the two strategies?

In this regard, translating CSIs presents a particular challenge: the role of culturespecific content in literary texts is to set them against a specific cultural background, or as Davies (2003: 72) remarks, to give them an authentic local flavour. Making a text familiar and accessible to the target audience may result in the loss of this authentic flavour. On the other hand, preserving the CSIs of the source text as much as possible might make the target text incomprehensible to the readers.

\subsection{Aims of the paper}

The aims of this paper are to establish whether the final year students have acquired enough cultural competence to successfully translate CSIs. Achieving a successful transfer from the source language/culture to the target language/culture will depend on whether the students have developed an awareness of the importance of intercultural communication and acquired enough theoretical knowledge of both intercultural phenomena and translation procedures. The students were already familiar with Newmark's cultural categories and procedures outlined in his book $A$ Textbook of Translation (1988). In the Intercultural Communication and Translation course, the students were introduced to the procedures for translating CSIs, which were proposed by Davies (2003):

- Preservation + Literal translation (maintaining the SL/SC reference, or translating it literally, with no further explanation)

- Addition (supplementing CSIs with additional explanation: paraphrase, footnotes, gloss)

- Omission (leaving out a problematic CSI altogether)

- Globalization (finding a more neutral or general reference)

- Localization (finding an equivalent cultural reference in the TL/TC)

- Transformation (modifying CSIs beyond globalization or localization)

- Creation (creating CSIs not present in the original text) 
The paper will also examine which of the above translation procedures were employed in translating the CSIs, and analyse the mistranslations and the possible causes.

The results of the examination above should serve a double purpose: at the micro-level, assessing the effectiveness of the individual course, and at the macrolevel, establishing, at least partly, whether the final year students have developed intercultural awareness. The data should be useful to both program administrators and course teachers in identifying the possible issues and making changes to achieve better learning outcomes at both levels.

\section{Methodology}

The study was done through the analysis of translation procedures employed by the students while translating the CSIs from four excerpts of literary texts. There were 45 translations in total, 23 from the 2017/18 class, and 22 from the 2018/19 class. Most students $(95.74 \%)$ had Serbian as their first language, with only two students $(4.26 \%)$ who were non-native Serbian speakers. Their level of English was heterogeneous, ranging from intermediate to advanced. All of them had passed their translation courses, as well as the courses in English literature and Anglo-American culture, so it was assumed that they would be sufficiently familiar with the cultural references in the four literary texts. The obtained results, in the form of Serbian translations, were categorized according to translation procedures, then explained and discussed.

\section{Results}

In the four excerpts, a total of 20 CSIs were selected and the students were asked to write their translations on a separate sheet. The four excerpts (Text 1, Text 2, Text 3 and Text 4) the CSIs they contain, and the results are presented below:

T1. Helen Fielding, Bridget Jones's Diary (1996). A popular British novel written in diary form, characterized by the use of colloquial language, and first-person narration. Four CSIs have been chosen:

- Awake on VE Day (1) in unseasonable heatwave trying to whip up frenzy of emotion in self about end of war, freedom of Europe, marvellous, marvellous, etc. etc.

- Maybe I should ring Tom and get a lovely party together for Bank Holiday Monday. (2)

- [...] the presence of Union Jacks (3) meant we were expecting skinheads (4) 
TRANSLATING CULTURE-SPECIFIC ITEMS IN LITERARY TEXTS

\begin{tabular}{|c|c|c|c|}
\hline English CSI & Meaning & $\begin{array}{c}\text { Students' } \\
\text { translations } \\
\text { (total no.) } \\
\end{array}$ & Procedures \\
\hline$\underline{\text { VE Day (1) }}$ & $\begin{array}{l}\text { Victory in Europe } \\
\text { Day (8 May in the } \\
\text { UK) }\end{array}$ & 40 & $\begin{array}{l}\text { Preservation/literal translation } 33 \\
\text { Addition } 3 \\
\text { Creation } 1 \\
\text { Transformation } 1 \\
\text { Mistranslations } 2\end{array}$ \\
\hline$\frac{\text { Bank Holiday }}{\underline{\text { Monday }(2)}}$ & $\begin{array}{l}\text { Bank Holiday - a } \\
\text { national public } \\
\text { holiday in the UK, } \\
\text { i.e. days when most } \\
\text { businesses are closed }\end{array}$ & 45 & $\begin{array}{l}\text { Generalization } 20 \\
\text { Creation/mistranslation } 16 \\
\text { Addition } 4 \\
\text { Transformation } 2 \\
\text { Preservation + Addition } 2 \\
\text { Generalization + Addition } 1\end{array}$ \\
\hline $\begin{array}{c}\text { The presence } \\
\text { of Union } \\
\text { Jacks (3) }\end{array}$ & The national UK flag & 40 & $\begin{array}{l}\text { Generalization } 25 \\
\text { Mistranslations } 5 \\
\text { Transformation } 3 \\
\text { Preservation } 2 \\
\text { Preservation + Addition } 2 \\
\text { Addition } 2 \\
\text { Omission } 1\end{array}$ \\
\hline$\underline{\text { Skinheads (4) }}$ & & 45 & $\begin{array}{l}\text { Preservation } 35 \\
\text { Transformation/Creation } 2 \\
\text { Generalization } 2 \\
\text { Addition } 2 \\
\text { Creation + Addition } 2 \\
\text { Transformation + Localization } 1 \\
\text { Mistranslation } 1\end{array}$ \\
\hline
\end{tabular}

Table 1. Students' translations of CSIs (English to Serbian) in Text 1

T2. Stephen King, "The Gingerbread Girl"6 (2014). In a short story by the popular American author of horror and mystery fiction, 4 CSIs have been selected:

- She lived in her Toughskins and shell tops (1)

- For two years in grammar school (2), their lunches were Scooby Snacks.

- One day, Becka lost her balance and came very close to falling fifteen feet (3) to the Jackson lawn.

- He even took time to kill the Briggs \& Stratton (4). 


\begin{tabular}{|c|c|c|c|}
\hline English CSI & Meaning & $\begin{array}{l}\text { Students' } \\
\text { translations } \\
\text { (total no.) }\end{array}$ & Procedures \\
\hline $\begin{array}{l}\text { She lived in } \\
\text { her Toughskins } \\
\text { and shell tops } \\
\text { (1) }\end{array}$ & $\begin{array}{l}\text { Toughskins - a line } \\
\text { of children's jeans } \\
\text { in the US, marketed } \\
\text { for their durability } \\
\text { shelltop - a type of } \\
\text { sleeveless blouse }\end{array}$ & 42 & $\begin{array}{l}\text { Generalization } 10 \\
\text { Generalization }+ \text { Addition } 10 \\
\text { Transformation } 9 \\
\text { Mistranslation } 6 \\
\text { Localization } 3 \\
\text { Preservation + Addition } 2 \\
\text { Transformation + Localization } 2\end{array}$ \\
\hline$\frac{\text { Grammar }}{\text { school (2) }}$ & $\begin{array}{l}\text { (UK) a state } \\
\text { secondary school } \\
\text { (US) another term } \\
\text { for elementary } \\
\text { school }\end{array}$ & 45 & $\begin{array}{l}\text { Mistranslation (localization, } \\
\text { generalization) } 37 \\
\text { Generalization } 7 \\
\text { Transformation } 1\end{array}$ \\
\hline Fifteen feet (3) & 1 foot $=$ cca. $0,30 \mathrm{~m}$ & 44 & $\begin{array}{l}\text { Localization } 31 \\
\text { Transformation } 5 \\
\text { Preservation } 4 \\
\text { Mistranslation } 3 \\
\text { Omission } 1\end{array}$ \\
\hline $\begin{array}{l}\text { He even took } \\
\text { time to kill } \\
\text { the Briggs and } \\
\underline{\text { Stratton }(4)}\end{array}$ & $\begin{array}{l}\text { A type of lawn } \\
\text { mower engine, } \\
\text { manufactured in the } \\
\text { US }\end{array}$ & 42 & $\begin{array}{l}\text { Generalization } 28 \\
\text { Preservation + Addition } 12 \\
\text { Omission } 2 \\
\text { Mistranslation } 1\end{array}$ \\
\hline
\end{tabular}

Table 2. Students' translations of CSIs (English to Serbian) in Text 2

T3. Margaret Atwood, The Blind Assassin (2000). A novel of historical fiction, winner of many literary awards, including the Man Booker Prize in 2000. Six CSIs have been selected:

- "Mind your own beeswax," (1) said Reenie.

- "Little pitchers have big ears," (2)

- "Not that she's got much to show, she's one of those flappers (3), she's flat as a boy. "

- "She's two bricks short of a load " (4)

- "I met her coming back across the lawn, with only a towel and what God gave $\underline{\text { Eve }}^{\text {" }}(5)$

- "She's a gold-digger " (6) 


\begin{tabular}{|c|c|c|c|}
\hline English CSI & Meaning & $\begin{array}{l}\text { Students' } \\
\text { translations } \\
\text { (total no.) }\end{array}$ & Procedures \\
\hline $\begin{array}{l}\text { Mind your own } \\
\underline{\text { beeswax }(1)}\end{array}$ & $\begin{array}{l}\text { A slang rendition of the } \\
\text { phrase "Mind your own } \\
\text { business" }\end{array}$ & 43 & $\begin{array}{l}\text { Preservation } 36 \\
\text { Localization } 2 \\
\text { Omission } 2 \\
\text { Mistranslation } 2 \\
\text { Creation } 1\end{array}$ \\
\hline $\begin{array}{l}\text { Little pitchers } \\
\underline{\text { have big ears }(2)}\end{array}$ & $\begin{array}{l}\text { A coded reminder to be } \\
\text { careful about what one } \\
\text { says in the presence of } \\
\text { children, as they often } \\
\text { understand much more } \\
\text { than adults realize }\end{array}$ & 44 & $\begin{array}{l}\text { Mistranslation (localization, literal } \\
\text { translation, creation) } 22 \\
\text { Generalization } 10 \\
\text { Localization } 5 \\
\text { Creation } 5 \\
\text { Omission } 2\end{array}$ \\
\hline $\begin{array}{l}\text { She's one of } \\
\text { those flappers (3) }\end{array}$ & $\begin{array}{l}\text { A fashionable young } \\
\text { woman intent on } \\
\text { enjoying herself and } \\
\text { flouting conventional } \\
\text { standards of behaviour } \\
\text { (in the 1920s). }\end{array}$ & 44 & $\begin{array}{l}\text { Omission } 12 \\
\text { Creation } 11 \\
\text { Localization } 8 \\
\text { Generalization } 7 \\
\text { Mistranslation } 6\end{array}$ \\
\hline $\begin{array}{l}\text { She's two bricks } \\
\text { short of a load (4) }\end{array}$ & $\begin{array}{l}\text { Not very intelligent, } \\
\text { of questionable mental } \\
\text { capacity }\end{array}$ & 38 & $\begin{array}{l}\text { Localization } 16 \\
\text { Creation } 10 \\
\text { Generalization } 6 \\
\text { Mistranslation (localization) } 6 \\
\text { Omission } 1\end{array}$ \\
\hline $\begin{array}{l}\text { With only a towel } \\
\text { and what God } \\
\text { gave Eve }(5)\end{array}$ & $\begin{array}{l}\text { Undressed, with no } \\
\text { clothes on }\end{array}$ & 44 & $\begin{array}{l}\text { Localization } 25 \\
\text { Preservation } 8 \\
\text { Transformation } 4 \\
\text { Omission } 7 \\
\end{array}$ \\
\hline $\begin{array}{l}\text { She's a gold- } \\
\text { digger (6) }\end{array}$ & $\begin{array}{l}\text { A woman who forms } \\
\text { relationships with men } \\
\text { purely to obtain money } \\
\text { or gifts from them }\end{array}$ & 38 & $\begin{array}{l}\text { Localization } 35 \\
\text { Generalization } 2 \\
\text { Mistranslation } 1\end{array}$ \\
\hline
\end{tabular}

Table 3. Students' translations of CSIs (English to Serbian) in Text 3

T4. John Fowles, "The Enigma" (1974). In a short story by the internationally acclaimed British author, published in his short story collection The Ebony Tower, 6 CSIs have been chosen:

- [...] a joint - if somewhat honorary - master of fox-hounds (1)

- [...] the successful City man (2) who is also a country land-owner and (in all but name) village squire. (3)

- [...] no accomplice among those who had formerly known the MP (4) suggested 
himself or herself.

- [...] connoisseurs of the inexplicable likened the whole business to that of the Marie Celeste. (5)

- On Fleet Street (6) Fielding was tacitly declared 'dead' some ten days after the story first broke.

\begin{tabular}{|c|c|c|c|}
\hline English CSI & Meaning & $\begin{array}{l}\text { Students' } \\
\text { translations } \\
\text { (total no.) }\end{array}$ & Procedures \\
\hline $\begin{array}{l}\text { master of fox- } \\
\underline{\text { hounds }(1)}\end{array}$ & $\begin{array}{l}\text { The person } \\
\text { responsible for the } \\
\text { conduct of a fox hunt }\end{array}$ & 31 & $\begin{array}{l}\text { Generalization } 11 \\
\text { Transformation } 8 \\
\text { Mistranslation (literal } \\
\text { translation, transformation) } 6 \\
\text { Omission } 6\end{array}$ \\
\hline $\begin{array}{l}\text { the successful } \\
\text { City man }(2)\end{array}$ & $\begin{array}{l}\text { The financial } \\
\text { and commercial } \\
\text { institutions located in } \\
\text { the City of London }\end{array}$ & 39 & $\begin{array}{l}\text { Transformation } 18 \\
\text { Generalization } 13 \\
\text { Preservation } 3 \\
\text { Addition } 3 \\
\text { Mistranslation } 2\end{array}$ \\
\hline$\frac{\text { village squire }}{(3)}$ & $\begin{array}{l}\text { A chief landowner in } \\
\text { a rural area }\end{array}$ & 34 & $\begin{array}{l}\text { Preservation } 15 \\
\text { Localization } 10 \\
\text { Generalization } 5 \\
\text { Mistranslation } 4\end{array}$ \\
\hline $\begin{array}{l}\text { no accomplice } \\
\text { among those } \\
\text { who had } \\
\text { formerly } \\
\text { known the MP } \\
\text { (4) suggested } \\
\text { himself or } \\
\text { herself }\end{array}$ & $\begin{array}{l}\text { Member of } \\
\text { Parliament (UK) }\end{array}$ & 29 & $\begin{array}{l}\text { Preservation } 12 \\
\text { Localization } 9 \\
\text { Mistranslation } 3 \\
\text { Omission } 3 \\
\text { Preservation + Addition } 2\end{array}$ \\
\hline
\end{tabular}




\begin{tabular}{|l|l|l|l|}
\hline $\begin{array}{l}\text { connoisseurs of } \\
\text { the inexplicable } \\
\text { likened the } \\
\text { whole business } \\
\text { to that of the } \\
\text { Marie Celeste. }\end{array}$ & $\begin{array}{l}\text { An American } \\
\text { merchant ship } \\
\text { discovered adrift } \\
\text { and deserted in the } \\
\text { Atlantic Ocean in } \\
1872 \text { The mystery } \\
\text { of the crew's } \\
\text { disappearance } \\
\text { has never been } \\
\text { explained. }\end{array}$ & 39 & $\begin{array}{l}\text { Preservation 8 } \\
\text { Omission 2 } \\
\text { Mistranslation 2 }\end{array}$ \\
\hline $\begin{array}{l}\text { On Fleet Street } \\
\text { (6) Fielding was } \\
\text { tacitly declared } \\
\text { dead' }\end{array}$ & $\begin{array}{l}\text { British national } \\
\text { newspapers and } \\
\text { journalists who work } \\
\text { for them }\end{array}$ & 35 & $\begin{array}{l}\text { Generalization 14 } \\
\text { Addition 4 } \\
\text { Omission 3 }\end{array}$ \\
\hline
\end{tabular}

Table 4. Students' translations of CSIs (English to Serbian) in Text 4

\section{Discussion}

The four literary texts contain culture-related content which gives them a specific setting and local flavour: T1's cultural background is 1990s urban London, or in the case of T4, a more traditional London of the 1970s; T2 is set against a distinctly U.S. American background, while T3 contains many historical references and expressions that evoke Canadian society and culture of the 1920s and 1930s.

\subsection{T1: Helen Fielding, Bridget Jones's Diary}

In $\mathrm{T} 1$, the majority of the students translated the CSIs correctly: $82.50 \%$ of the students translated VE Day (1) using preservation/literal translation as Dan pobede (Victory Day), 62.50\% of the students translated Union Jacks (3) using globalization as britanske zastave or nacionalne zastave (British/national flags), and $77.78 \%$ preserved skinheads (4) as skinhedi or skinhedsi. Only in the case of Bank Holiday Monday (2) did a significant number of mistranslations occur: $44.44 \%$ correctly translated this CSIs as državni praznik (national holiday) using globalization, or neradni ponedeljak zbog državnog praznika, paraphrasing the translation to include an additional explanation. A number of other students (35.56\%), most likely unfamiliar with the CSI in question, opted for preservation/literal translation, resulting in phrases such as praznik banaka, nacionalni Dan banke, or Benk Holidej - dan odmora za banke. In this case, although the students aimed to preserve the CSI, we can propose that they have used another procedure - creation, and created a CSI not present in the source text. 


\subsection{T2: Stephen King, "The Gingerbread Girl"}

T2 seems to have presented somewhat more of a challenge: $47.62 \%$ of the students translated Toughskins and shell tops (1) as farmerke i majice bez rukava using globalization, or combining globalization with addition (izdržljive pantalone $i$ majice bez rukava, široke farmerke i majice). Some students opted for localization (zvoncare i majice na bretele), yet others for preservation ("Toughskins" farmerke i majice bez rukava). A significant number of students (21.43\%), perhaps due to the overall informal tone of $\mathrm{T} 2$, decided to be more free in their translations, resulting in the phrases such as tesne farmerke i topići, dečačke farmerke i patike, Tafskins farmerice i kratke majice bez rukava, which could be categorized under transformation - modifying CSIs beyond globalization or localization. Interestingly, some students understood the CSI as a metaphor for the protagonist's state of mind as a young girl (quiet and withdrawn, not coming out of her shell), which resulted in mistranslations such as bila je kao kakav debelokožac u svojoj školjci, živela je u svom oklopu od tvrde kože, or živela je u svom svetu sa veoma odbojnim stavom.

Grammar school (2) seemingly the most straightforward CSI of all, proved to have the most mistranslations: $82.22 \%$ of the students translated it as gimnazija or srednja škola (secondary/high school), using localization and globalization respectively, but the correct translation would in fact be osnovna škola (primary/elementary/middle school), used only in 7 out of 45 translations $(15.56 \%)$. The confusion arises from the fact that the same term stands for different levels of education in the UK and the US. Still, the students seemed to not have paid enough attention to the context, as girls of secondary school age could hardly be envisioned climbing trees, which is what the protagonist describes herself and her best friend doing during their primary school years.

Most of the students (70.45\%) correctly translated fifteen feet (3) as $4(4,5 / 5)$ metara, using localization. Some of them (15.56\%) used preservation, translating it as petnaest stopa. In this case, preservation is unjustified, as the purpose of the phrase is to illustrate the height from which one of the young girls fell, and how it felt to her like a much greater height than it really was. Therefore, it is essential that it is expressed in the units of measure familiar to the readers of the target text.

The Briggs and Stratton (4), a US brand of a lawn mower engine, was correctly translated by most of the students $(71.43 \%)$ as kosilica, motor kosilice, kosilica za travu, kosačica, using globalization, or alternatively as kosilica „Brigs i Straton” $(27.27 \%)$, combining preservation and addition.

\subsection{T3: Margaret Atwood, The Blind Assassin}

T3 contains less straightforward and more informal CSIs, which students tried to convey into the target language with varying success. Mind your own beeswax (1), 
as a slang rendition of a familiar rebuke, was translated as Gledaj svoja posla by an overwhelming majority of students $(83.72 \%)$. This translation, however, seems to be one of the cases of the transposition of English lexical and semantical structures into Serbian. A much better solution was offered only by 2 out or 43 students $(4.56 \%)$ : To se tebe ne tiče, or Brini svoju brigu, which sounds more natural in Serbian. Interestingly, one student attempted to create an analogical saying in Serbian Gledaj svoj posak (blending posao $=$ business and vosak $=$ wax), but also provided additional explanation in the form of a footnote.

The expression Little pitchers have big ears (2) was correctly recognized as a proverbial saying by the students, but no fewer than half of them $(50.00 \%)$ incorrectly translated it with a Serbian proverbial saying I zidovi imaju uši , although the meanings of the two phrases are incongruous. Some mistranslations were due to either basic misunderstanding of the proverb and the context, or to the tendency for literal translation into Serbian that the students are most often exposed to, and resulted in phrases such as Mali ćupovi imaju velike uši, Mali bacači imaju velike uši , both of which are meaningless in Serbian. 27.73\% of the students opted for generalization and addition, paraphrasing the saying as Pazi, deca slušaju, Deca nas slušaju, Nemoj pred decom, or Moramo paziti šta pričamo pred decom. Five students (11.36\%) translated the phrase using localization, as Deca su kao sunđer, Deca sve upijaju kao sunđer. The same number of students even attempted creation, translating the saying as Mala deca imaju velike uši, which might be an interesting solution. The phrase resembles authentic Serbian proverbs, even containing a metonymic relationship between the concepts imaju velike uši ('to have big ears') = pažljivo slušaju, sve čuju ('to listen closely or attentively').

A flapper (3) was evidently one of the CSIs that were the most challenging for the students. $27.27 \%$ of the students opted to omit the CSI altogether, choosing globalization or paraphrase instead. $25 \%$ chose preservation and translated it as flaperka, thus attempting to create a CSI in the target language, although this term is completely unfamiliar to Serbian readers, and would require additional explanation. 2 students (4.56\%) also attempted creation, but using Serbian: daskara or daskača, which would be a derogatory term for a flat-chested woman; however, this still does not correspond to the meaning of flapper. $18.18 \%$ of the students attempted to find a similar expression in the target language, and incorrectly translated the CSI as siparica. This Serbian term actually denotes an adolescent girl, who is due to her young age very impressionable and easily excitable, and is often used derisively. In this case, the best option was to omit the CSI and translate the phrase using generalization and/or addition, as in the following examples: ona je jedna od onih slobodnih žena, ona je jedna od onih devojaka što prate modu. 
Most of the students recognized that She's two bricks short of a load (4) is a pejorative idiomatic expression which requires localization. $42.11 \%$ found corresponding expressions in Serbian, such as fali joj koja daska u glavi, bistra je k'o boza, nije sva svoja. 26.32\% combined the English and Serbian phrases, resulting in the creation of a CSI fale joj dve daske u glavi, an expression that does not actually exist in Serbian. Six of the students (15.79\%) opted for generalization, paraphrasing the CSI as nije baš inteligentna, nije baš bistra, nije baš pametna. The same number of students mistranslated the CSI using overly emphatic expressions such as glupa k'o noć, glupa k'o tocilo or incongruous expressions such as nisu joj sve koze na broju ('feeling out of sorts').

The euphemistic expression what God gave Eve (5) was translated with an equivalent euphemistic simile in Serbian kao od majke rođena (i.e. "in her birthday suit'), or a more explicit one gola kao od majke rođena ('naked as on the day she was born'), by $56.82 \%$ of the students. Eight students (18.18\%) chose to preserve this expression and translated it literally with ono što je Bog dao Evi, even though this does not exist as a set phrase in Serbian. Four students (9.09\%) attempted to modify the CSIs beyond localization and used transformation, which resulted in ono što joj je Bog podario. This phrase sounds more natural in Serbian, although it is rather vague and does not have the same implication as in English. Seven students (15.91\%) omitted the CSI altogether.

Gold-digger (6) was almost universally translated using localization as sponzoruša, by 35 out of 38 students $(92.11 \%)$. However, T3 is an excerpt from a novel set in the 1920s, while this Serbian expression, denoting a woman who enters a relationship with a rich and/or powerful man with the aim of using her sexuality to secure financial or other kinds of support, is relatively modern. It is true that both are derogatory terms, but sponzoruša is a colloquial expression, which comes across as too informal, even substandard. In this case, a better solution would be to paraphrase the expression, using globalization and/or addition. Only 2 students actually attempted this, translating the phrase with varying success as ona je koristoljubiva, ona je lovac na blago.

\subsection{T4: John Fowles, "The Enigma"}

It seems that the students found the CSIs in T4 the most difficult to translate. 5 out of 44 students did not attempt to translate this text at all, and 10 more students translated only half of it or only some of the phrases. The number of students who translated the individual CSIs ranged from 39 to as few as 29. This is perhaps understandable, as the short story "The Enigma" is set in a more traditional background of 1970s urban London, describing the aftermath of the mysterious disappearance of 
one of its prominent citizens. Therefore, it abounds with culturally charged phrases, such as master of fox-hounds, village squire, or Marie Celeste.

In point of fact, master of fox-hounds (1) is one of the three CSIs that was translated by the lowest number of students. Out of 31 students who translated the fragment, $6(19.35 \%)$ omitted the phrase altogether. As for the rest, 11 students (35.48\%) attempted to translate the CSI using globalization and/or addition, which is the best solution in this case. Their translations ranged from the very accurate, such as predsednik udruženja lovaca na lisice, to the more general, such as glavni lovac or lovac. $19.35 \%$ of students offered mistranslations such as gospodar lisičara, gospodar lova na lisice, gospodar pasa lisičara, or even gospodar lisica, most probably due to the students' insufficient understanding of the concept itself and their go-to response to translate literally. $25.81 \%$ of the students modified the CSI beyond generalization and provided translations such as vlasnik engleskih lisičara, suvlasnik lovačkih pasa, or even uzgajivač pasa lisičara, although the text offers nothing to suggest that the character in question is either an owner or a breeder of fox-hounds.

The phrase the successful City man (2) was translated by 18 out of 39 students (46.15\%) as uspešan gradski čovek, which can be categorized as transformation, going a step beyond globalization. In this case, however, transformation may be an acceptable procedure, as the text goes on to draw a comparison between the character's urban persona (the successful City man) and his responsibilities in the country (a country land-owner). $33.33 \%$ opted for generalization, and provided translations such as uspešni poslovni čovek, or the less successful uspešan gradski biznismen. As the City stands for the central business district of London, the collocation poslovni čovek conveys the meaning to the target language adequately enough. Three students $(7.69 \%)$ chose preservation, translating the CSI as uspešni Siti čovek, which is not transparent enough in the target language and may mean very little to the reader. Moreover, this translation violates one of the basic rules of Serbian grammar: personal names are not normally found in premodification of common nouns (Novakov 2008: 95), so the structure should be uspešan čovek iz Sitija. It is precisely this translation that 3 other students chose, one of them adding the explanation of the term Siti in a footnote.

Village squire (3) was translated by 34 students. 15 students $(44.12 \%)$ chose to use preservation/literal translation, and provided solutions ranging from seoski plemić to seoski vitez to seoski štitonoša. These translations are either incongruous with the overall context (seoski plemić, seoski vitez), or are wide of the mark (seoski štitonoša), and are probably due to the students' misunderstanding of the CSI in question, as well as their insufficient background knowledge and information literacy. However, 15 students evidently understood what the CSI refers to, so 5 of them $(14.71 \%)$ chose to use localization, and provided translations such as seoski starešina or seoski vlastelin. 
These translations, although slightly better than those obtained using preservation, still are not accurate enough. 10 students $(29.41 \%)$ chose to use globalization, which resulted in a number of successfully paraphrased expressions such as prvi čovek $u$ selu, glavni čovek u selu or veleposednik, which adequately convey the intended meaning. Finally, 4 students (11.76\%) completely mistranslated the CSI (seoski sabor, vlasnik seoskog trga, seoski radnik), probably due to paying insufficient attention to the text, rushing to finish the task, or simply not possessing enough background knowledge and information literacy to understand the context.

The MP (4) was, surprisingly, one of the three CSIs with the lowest number of translations. In this case, the most likely reason is that $\mathrm{T} 4$ proved to be the most difficult for the students, so 10 of them translated only the first half of it, and the MP is in the second half. Out of 29 students who translated the CSI, 12 (41.38) unfortunately opted for preservation/literal translation član parlamenta, and 2 more students $(6.90 \%)$ even decided to keep the abbreviation in the target text and to insert an explanatory footnote. Needless to say, both procedures (preservation, preservation and addition) are unsuitable, as Serbian has the semantic equivalent of this CSI - (narodni) poslanik, a localized translation that 9 students $(31.03 \%)$ correctly supplied. Three students $(10.34 \%)$ omitted the CSI, and the same number mistranslated it as nestala osoba, nestalo lice, inferring that the abbreviation MP stands for "missing person".

The reference to the case of Marie Celeste (5) was evidently correctly understood by the majority of the students who translated T4, as there were very few omissions and mistranslations. Out of 39 students, 27 (69.23\%) translated the CSI using addition (most frequently as intratextual gloss): čuveni nestanak svih članova posade sa broda Mari Selest, slučaj napuštenog broda Mari Selest, sa misterioznim brodom Mari Selest, nestanak Mari Selest, nestanak posade na brodu Mari Selest. The translations referencing the disappearance of the crew rather than the ship are more accurate, and adding the adjectives such as čuveni or misteriozni can be helpful in establishing the reference as an epitome of the mysterious and the unexplained in the target readers' minds. The less fortunate procedure, employed by 8 students $(20.51 \%)$, was preservation/literal translation, where the structure was transferred without any additional explanation, and in some cases without transliteration either: sa slučajem Meri Selest, u Marie Celeste, sa Mari Selest. It is highly unlikely that the Serbian readers would be familiar with the reference, especially as these translations give the impression that Marie Celeste is a person, rather than a ship. These students probably thought the same, and felt no need to check whether they were correct. There were only two mistranslations that were wide off the mark: Marija Terezija and trgovac brilijantima Marie Celeste. The first would be familiar to Serbian readers as the name of $18^{\text {th }}$ century Austro-Hungarian empress; the second probably has to do with the 
fact that Marie Celeste was a merchant ship (trgovac = merchant). However, the reasons why the students used the proper name Marija Terezija and the phrase meaning 'diamond merchant' could only be discovered by talking to the students themselves.

The CSI Fleet Street was translated by 33 students, while 3 more students who translated this fragment omitted it. Interestingly, the equal percentage of students used the procedures of preservation and globalization (42.42\%). In this case, globalization is the best procedure to use, as the CSI refers to British national newspapers: britanska štampa, novinske kuće, mediji, or even među novinarima all convey the meaning of the CSI adequately enough. Using preservation, as in the translations na Flitstritu, *u "Fleet Street"-u, u ulici Flit, na Flit Strit, etc. renders the meaning opaque in the target language, since the reference to the London street would probably mean very little to Serbian readers. Four students $(12.12 \%)$ chose to use preservation and addition, and supplied translations such as na Ulici Flit (with an explanatory footnote) or a long intratextual gloss $u$ londonskoj ulici, Flit strit, koja je sedište novinarstva. Of course, a simple structure such as britanska štampa is preferable, as it is much more economical and effective.

Examining the results in general, we can conclude that most of the students used the correct translation procedure for 13 out of 20 CSIs (65\%). For the 7 CSIs, incorrect translation procedures were used, which resulted in mistranslations. In T2, the mistranslated CSI was grammar school; in T3, the difficult CSIs were Mind your own beeswax, Little pitchers have big ears, flapper and a gold-digger. In T4, they were village squire and MP. Analysing the mistranslated CSIs, we can conclude that one of the reasons for mistranslations are probably the general tendency towards literal translation in Serbian (evident in the media and literary translations, which the students predominantly consume). This tendency includes the literal translations of both phrases (e.g. MP) and structures (e.g. Mind your own beeswax). The other reason might be that the students are unaccustomed to or unwilling to devote additional effort to searching for an adequate cultural equivalent in the target language. Naturally, the role of teachers/examiners is crucial in setting the students on the right path or correcting any misperceptions they might have. Therefore, the translation courses should include more in-class discussions about culture-specific content and the correct procedures to translate such content, so as to provide students with adequate feedback.

\section{Conclusion}

Overall the results suggest that most of the analysed translations were supplied using an adequate procedure for translating culture-specific references. Therefore, we can conclude that at the micro-level, the translation courses effectively provided most students with the basic knowledge of translation techniques and strategies. In particular, 
the Intercultural Communication and Translation course has stressed the importance of intercultural awareness for communication and translation, focusing on the translation procedures for culture-specific content. At the macro-level, the students who chose correct procedures can also be said to have developed enough intercultural awareness to be able to understand the CSIs in the source text, and to find the appropriate culturerelated equivalents for the target text.

The way to achieve better results at both levels would be to encourage students to consistently improve their language skills, to devote more time and effort to research unfamiliar phrases and concepts, and to become more knowledgeable about both the source and target culture by reading extensively. They should be reminded that one of the basic goals of their studies is to develop communicative competence, which includes translation. A competent translator should be a mediator between the source and target culture, constantly finding the right balance between foreignization and domestication. Without intercultural awareness and a vast background knowledge, the result can only be an inadequate and misinformed translation. In order to increase intercultural awareness and information literacy, the translation courses should be adapted to include more information about English-speaking countries and cultures, so as to promote the students' overall sociocultural competence. Moreover, assessment criteria for translation courses should be modified to assess not only the finished product, i.e. the translated texts the students submit, but also the process and research that led to it. This could be achieved by in-class discussions, analysing the source language texts and asking students to compile glossaries on specific topics of research. In this way, the students could set up their own glossaries of culture-related items, which would be very helpful should they choose a career in translation.

\section{References}

Aixela, J. F. (1996). Culture-Specific Items in Translation. In: R. Alvarez and M. C. A. Vidal (eds.), Translation, Power, Subversion, Clevedon: Multilingual Matters, $52-78$.

Baker, M. (1992). In Other Words: A Coursebook on Translation. London and New York: Routledge.

Ceramella, N. (2008). Linking Theory with Practice: The Way to Quality Translation. In: A. Nikčević-Batričević and M. Knežević (eds.), Culture-Bound Translation and Language in the Global Era, Cambridge: Cambridge Scholars Publishing, $3-32$. 
Celce-Murcia et al. (1995). Communicative competence: A pedagogically motivated model with content specifications. Issues in Applied Linguistics, 6(2), 5-35.

Commission for Accreditation and Quality Assurance: Rules and Standards. (16 September 2019) <http://www.kapk.org/en/accreditation/>.

Davies, E. E. (2003). A Goblin or a Dirty Nose? The Translator, 9:1, 65-100. doi:10.1 080/13556509.2003.10799146

Fernandez Guerra, A. (2012). Translating Culture: Problems, Strategies, and Practical Realities. [sic] - a journal of literature, culture and literary translation, 3:1, 1-27. doi: 10.15291/sic/1.3.1t.1.

Gambier, Y. (2007). Doubts and Directions in Translation Studies. Amsterdam: John Benjamins.

Graddol, D. (2000). The Future of English? A guide to forecasting the popularity of English in the $21^{\text {st }}$ century. (11 November 2019) <https://s3.amazonaws.com/ academia.edu.documents/33032011/future_of_english.pdf $>$.

Hervey, S. and I. Higgins (1992). Thinking Translation: A Course in Translation Method. London and New York: Routledge.

James, A. 2008. Lingua Franca - Cultura Franca? In: A. Nikčević-Batričević and M. Knežević (eds.), Culture-Bound Translation and Language in the Global Era, Cambridge: Cambridge Scholars Publishing, 46-62.

Larson, M. L. (1984). Meaning-Based Translation: A Guide to Cross-Language Equivalence. Lanham and New York: University Press of America, Inc.

Newmark, P. (1988). A Textbook of Translation. New York and London: Prentice-Hall.

Nord, C. (1997). Translating as a Purposeful Activity: Functionalist Approaches Explained. Manchester: St. Jerome.

Novakov, P. (2008). Anglističke teme. Novi Sad: Futura publikacije.

Novakov, P. (2016). Kulturološki elementi u prevodu: suočavanje sa drugima. CIVITAS - časopis za društvena istraživanja, 6(2), 108-120.

Prćić, T. et al. (2001). Du yu speak anglosrpski? Rečnik novijih anglicizama. Novi Sad: Zmaj.

Prćić, T. (2011). Engleski u srpskom. Novi Sad: Zmaj.

Sentov, A. (2017). Translating Culture-Bound Elements in James Shapiro's 1606: Shakespeare and the Year of Lear. CIVITAS - časopis za društvena istraživanja, 1(7), 17-31.

Venuti, L. (1995). The Translator's Invisibility: A History of Translation. London: Routledge. 